\title{
The Effect of Policy Implementation, Personnel Competency, and Community Participation on the Performance of the department of Women Empowerment, Child Protection and Community Empowerment, Medan, Indonesia
}

\author{
Robert Antonius Napitupulu ${ }^{1}$; Tjahja Supriatna ${ }^{2}$; H. Musa Hubeis ${ }^{2}$; Dewi Sulistyani ${ }^{2}$ \\ ${ }^{1}$ Student of Doctorate Program on Public Administration, Satyagama University, Indonesia \\ ${ }^{2}$ Lecturer of Doctorate Program on Public Administration, Satyagama University, Indonesia
}

http://dx.doi.org/10.18415/ijmmu.v8i1.2388

\begin{abstract}
The background of this research is the low performance of the Office of Women's Empowerment, Child Protection and Community Empowerment (P3PAD) Medan City. This study aims to analyze and understand the effect of policy implementation, HR competence, and community empowerment on the performance of the Medan City P3APD office either partially or jointly. This research focuses on the variables of Policy Implementation, HR Competence, Community Empowerment and Performance. This research method is a quantitative approach method, data collection techniques using documentation techniques, questionnaires, and literature study. This research data collection tool is a questionnaire based on the Likert scale, observation, interviews. The data analysis technique in this research is validity test, $\mathrm{F}$ test and t test. The sampling technique in this study was proportionate stratified random sampling. The results of this study prove that Policy Implementation has an effect of $83.6 \%$, HR Competence has an effect of $99.9 \%$, Community Participation has an effect of $91.3 \%$, Policy Implementation, HR Competence and Community Empowerment together have an effect of 99.9\%. on the Performance of the Office of Women's Empowerment, Child Protection and Community Empowerment (P3PAD) Medan City. As a recommendation for the results of this study, namely: (1) carry out monitoring and evaluation of local regulations related to DP3APM agencies so that it describes the financing of work programs supported by the e-budgeting system, e-money for community empowerment in Medan City, etc., (2) increasing cooperation between multi stakeholders in the city Medan in increasing the competence of human resources through increasing knowledge based on science and technology and IMTAQ, (3) The regional government is expected to involve stakeholders in the health sector in order to increase the effectiveness of the community empowerment program in Medan City through socialization efforts, ToT, training and workshops so that occupational health and safety are in empowerment programs. Medan city community is more secure.
\end{abstract}

Keywords: Policy Implementation; Apparatus Competence; Community Participation and Performance 


\section{Introduction}

Presidential Regulation Number 2 of 2015 concerning the State Medium Term Development Plan (RPJMN) 2015-2019, there are five national development agendas, one of which is "Building transparency and accountability for government performance". This means that the Central Government wants to realize good governance, where one of the principles of good governance is accountability. Strengthening performance accountability is one of the programs implemented in the framework of bureaucratic reform to create a clean and free government from $\mathrm{KKN}$, improving the quality of public services to the community and increasing the capacity and accountability of bureaucratic performance (LAKIP Pemkot Medan, 2015).

Mazmanian and Sabatier (in Wahab, 2002: 68), Implementation is the implementation of basic policy decisions, usually in the form of laws, but can also be in the form of orders or important executive decisions or judicial decisions. Typically, the decision identifies the problem to be discussed, states explicitly the goals / objectives to be achieved, and various ways to structure /organize the implementation process. Tachjan (2006: 25) states that public policy implementation is a process of administrative activities that is carried out after the policy is determined and approved. This activity lies between policy formulation and policy evaluation. Policy implementation contains top-down logic, which means reducing or interpreting alternatives that are still abstract or macro into concrete or micro alternatives.

Performance is the result of work that has a strong relationship with the organization's strategic goals, customer satisfaction, and contributes to the economy (Wibowo, 2016). Performance has become one of the organizational keywords ranging from corporate organizations, government organizations, and also universities. Likewise, performance is included in every social and economic aspect of society. This condition can be seen from many organizations that include the word performance in their vision and mission. Achievement of performance is not only expected for employees but in the long term it is expected to be able to improve institutional performance.

Table 1. Realization of the Performance of Women Empowerment, Child Protection and Community Empowerment Service (DP3APM) Medan, in 2018

\begin{tabular}{|l|l|c|}
\hline NO & Details & $\begin{array}{c}\text { Realization } \\
(\%)\end{array}$ \\
\hline $\begin{array}{l}\text { I. } \text { Increased women's participation in regional development } \\
\text { processes }\end{array}$ & \\
\hline 1 & Women' Labor Force Participation & 53,94 \\
\hline 2 & Women' Participation in Government Institution & 2,26 \\
\hline 3 & Women' Participation in Private Institution & 0,30 \\
\hline 4 & Percentage of women in legislature & 10 \\
\hline $\begin{array}{l}\text { Increasing the quality of the protection system for women, children } \\
\text { and the fulfilment of children's rights }\end{array}$ & \\
\hline 5 & $\begin{array}{l}\text { Percentage of complaints handling women and children } \\
\text { protection from acts of violence }\end{array}$ & 100 \\
\hline Increasing Productive Group in Society & 100 \\
\hline 6 & Percentage of Active Posyandu & 99 \\
\hline 7 & The average number of PKK assisted groups \\
\hline
\end{tabular}

Sumber: P3APM Department, Medan, 2019

Based on Table 1. The realization of the performance of the Medan City P3APM Service in 2018, while the strategic target with the highest achievement is the second goal, namely improving the quality

The Effect of Policy Implementation, Personnel Competency, and Community Participation on the Performance of the department of Women Empowerment, Child Protection and Community Empowerment, Medan, Indonesia 
of the protection system for women, children and the fulfillment of children's rights by $100 \%$. Number of case reports of complaints of violence against women and children that were received and followed up by the Office of Women's Empowerment, Child Protection and Community Empowerment. The activities that support the success of this strategic goal are the availability of an operational budget for handling cases of violence against women and children. Meanwhile, the strategic target with the lowest achievement was increased women's participation in the regional development process, the indicator for women's participation in private institutions was $0.30 \%$. This is due to the low quality of female human resources in terms of formal and non-formal education.

According to Armstrong (1998), performance appraisal is based on understanding the knowledge, skills, expertise and behavior required to do a job well and a broader analysis of individual attributes and behavior. An objective performance appraisal will provide appropriate feedback on changes in behavior towards the expected productivity increase in performance. There are various forms of performance appraisal, such as key performance indicators or key performance indexes, which are basically a goal and a systematic process to collect, analyze and use information to determine the efficiency and effectiveness of employee tasks and target achievement.

Robbins (2005: 37) mentions competence as ability, namely the capacity of an individual to do various tasks in a job. Furthermore, it is said that individual abilities are formed by two factors, namely intellectual abilities and physical abilities. Intellectual ability is the ability needed to carry out mental activities while physical ability is the ability needed to perform tasks that require stamina, dexterity, strength and skill.

Table 2. Personnel Competence of DP3APM, Medan

\begin{tabular}{|l|l|l|l|l|}
\hline \multirow{2}{*}{ NO } & \multirow{2}{*}{ Details } & \multicolumn{3}{|l|}{ TOTAL } \\
\cline { 3 - 5 } & & $\mathbf{2 0 1 7}$ & $\mathbf{2 0 1 8}$ & $\mathbf{2 0 1 9}$ \\
\hline Educational Background & & & \\
\hline 1 & SD & 1 & 1 & 1 \\
\hline 2 & SMP & 0 & 0 & 0 \\
\hline 3 & SMA & 4 & 4 & 4 \\
\hline 4 & D3 & 4 & 4 & 4 \\
\hline 5 & S1 & 23 & 22 & 20 \\
\hline 6 & S2 & 9 & 10 & 12 \\
\hline 7 & S3 & 0 & 0 & 0 \\
\hline Working Time & & & \\
\hline 1 & $<1$ year & 3 & 2 & 1 \\
\hline 2 & $1-2$ year & 7 & 7 & 6 \\
\hline 3 & $<2$ year & 31 & 32 & 34 \\
\hline \multicolumn{2}{|l|}{ TOTAL } & 41 & 41 & 41 \\
\hline
\end{tabular}

Source : DP3APM Medan, 2019

Based on Table 2., It can be seen that the majority of Medan City DP3APM Apparatus Education is Bachelor (S1), and a minority of SD graduates are 1 person. Meanwhile, the majority of civil servants have worked for more than 2 years. The increase from year to year shows that changes in educational status have an impact on the competence of human resources. Competence is the basic basis for a person's characteristics in behaving or thinking, equating the situation, and supporting for a long period of time. Discipline, self-concept, social role, mentor quality, harmonious family relationships. Of all competency builders, commitment to achieving one's life goals is the strongest in determining the level of mastery of one's competence which ultimately affects one's performance. Therefore, employee competence can be used to predict which employees have good and poor performance based on the standards used. 
Community Participation according to Jim Ife (2008; 295), Participation is a concept in community development, used generally and widely. Participation is a central concept, and a basic principle of community development because, among many things, participation is closely related to the idea of human rights.

Therefore, improvements in various fields continue to be carried out, including by increasing organizational performance through policy implementation, human resource quality and community empowerment. One of the problems faced in community empowerment is an increase in organizational performance that reflects the ability of organizational members to work. Performance improvement is not only seen in terms of community empowerment in order to improve HR competencies, but is also influenced by job characteristics. To create quality human resources (HR), a competency is needed. If employees do not have competence, it will cause problems for the organization.

On that basis, research was carried out in Sarolangun Regency with the title: "The Effect of Policy Implementation, HR Competence and Community Empowerment on the Performance of the Office of Women Empowerment, Child Protection and Community Empowerment in Medan City", where the objectives of the study: (1) Analyze the magnitude of the influence of Policy Implementation on Performance Department of Women's Empowerment, Child Protection and Community Empowerment in Medan City. (2) Analyze the magnitude of the influence of HR competence on the Performance of the Office of Women's Empowerment, Child Protection and Community Empowerment in Medan City. (3) Analyze the magnitude of the influence of community empowerment on the performance of the Office of Women's Empowerment, Child Protection and Community Empowerment in Medan City. and (4) Analyzing the influence of Policy Implementation, HR competence, and community empowerment simultaneously on the Performance of the Office for Women's Empowerment, Child Protection and Community Empowerment in Medan City.

The benefits of this research are expected to provide the best input material for the people of Medan City, especially in the P3APM Office to improve organizational performance, as well as provide input for local governments in formulating policies that involve stakeholders to improve the performance of Regional Apparatus Organizations (OPD).

\section{Research Methodology}

Quantitative methods are used to explore the formulation of research problems. The data collection method in this research uses observation, interview, document, questionnaire, and literature study techniques. The sample was selected by simple random sampling, in which the sampling of members of the population was done randomly without considering the strata in the population (Sugiyono 2010).

There are three informants as the key person in this study, namely the Head of the P3APM Service and the Medan City DP3APM Employees. Location This research was conducted at the P3APM Office in Medan City. Time of Research Implementation on October 1, 2017 to January 31, 2018.

\section{Finding and Discussion}

\section{Effect of Policy Implementation on Performance}

The simple linear regression equation formed between the Policy Implementation variable (X1) and performance $(\mathrm{Y})$ is $\hat{\mathrm{Y}}=2.305+0.962 \mathrm{X} 1$. The results of these statistics indicate that the 
implementation of policies makes a significant contribution to performance. That is, the better the Policy Implementation, the better the performance with the Beta Coefficient value of 0.962 .

Based on the results of the above analysis, the implementation of policies partially has a large positive and significant influence on performance in the Office of Women's Empowerment, Child Protection and Community Empowerment in Medan City. This effect can be seen from the value of the determination coefficient $\left(\mathrm{R}^{2}\right)$ of 0.836 or equal to $(83.6 \%)$. This shows that $83.6 \%$ of Policy Implementation affects the performance of the Office of Women's Empowerment, Child Protection and Community Empowerment in Medan City, while the remaining $16.4 \%$ is caused by variables or other factors not examined in this study.

The above is in line with realizing performance in the Office of Women's Empowerment, Child Protection and Community Empowerment in Medan City that can be of quality and satisfy the community based on good policy implementation.

\section{Effect of Apparatus Competence on Performance}

There is a significant effect of the Apparatus Competence variable on performance. This can be seen from the results of hypothesis testing; the Sig value is obtained. $000<\alpha=0.05$, then the hypothesis is accepted, this shows that Apparatus Competence can improve performance in the Office of Women's Empowerment, Child Protection and Community Empowerment in Medan City. The simple linear regression equation formed between the Apparatus Competence (X2) and performance (Y) variables is $\hat{Y}$ $=-0,122+1,002 \mathrm{X} 2$. These statistical results indicate that Apparatus Competence makes a significant contribution to performance. This means that the better the Apparatus Competence, the better the performance with the Beta Coefficient value of 1.002 .

Based on the results of the analysis above, it is proven that the Apparatus Competence partially has a large positive and significant influence on the performance in the Office of Women's Empowerment, Child Protection and Community Empowerment in Medan City. This influence can be seen from the value of determination coefficient $\left(\mathrm{R}^{2}\right)$ of 0.999 or $99.99 \%$, which means that apparatus competence affects the performance of the Office of Women's Empowerment, Child Protection and Community Empowerment in Medan City, while the remaining 0.1\% is influenced by other variables not examined in the study. this.

A person's competence can be seen from the level of creativity he has as well as the innovations created and his ability to solve a problem. Competence is generally defined as a form of skills, knowledge, abilities and behavior of an employer / employee in carrying out duties (Indrajaya, 2017). As mentioned above, it can be said that the influence of Apparatus Competence is very much needed in the implementation of quality performance in the Office of Women Empowerment, Child Protection and Community Empowerment in Medan City, namely in order to achieve unity of action between units in one agency and another, so that what is desired to be achieved in an efficient and effective manner. This means that all tasks, activities and jobs related to the implementation of integrated performance towards the desired target, namely the quality of public services that satisfy the community.

\section{The Effect of Public Participation on Performance}

There is a positive and significant influence of Community Participation on the Performance of Health Services in the Office of Women's Empowerment,Child Protection and Community Empowerment in Medan City, seen from the Coefficient of Determination $\left(\mathrm{R}^{2}\right)$ of 0.913 or $91.3 \%$ while the remaining $8.7 \%$ is caused by factors others who were not examined in this study. The realization of effective Community Participation in quality is determined by standards of supervision, implementation and

The Effect of Policy Implementation, Personnel Competency, and Community Participation on the Performance of the department of Women 
corrective action as a natural process of determining performance measures in the Office of Women's Empowerment, Child Protection and Community Empowerment in Medan City.

Good community participation is basically fully directed at avoiding the possibility of diversion or deviation from the goals to be achieved in improving performance, especially in the Office of Women's Empowerment, Child Protection and Community Empowerment in Medan City. Through good community participation, it is hoped that it can help carry out the implementation of policies that have been determined to achieve the planned goals effectively and efficiently.

\section{The Effect of Policy Implementation (X1), Personnel Competence (X2), and Community Participation (X3) Together on Performance.}

The results showed that the Effect of Policy Implementation, Apparatus Competence, and Community Participation on Health Service Performance in the Office of Women's Empowerment, Child Protection and Community Empowerment in Medan City was $99.9 \%$. While the rest $(0.1 \%)$ is due to other variables that are not discussed in this study. This influence can be seen from the coefficient of determination of -0.167 . The recapitulation of the beta coefficient value is divided into main factors, supporting factors, and reinforcing factors. The main factor affecting performance is the HR Competency variable with a value of 0.996 units, the supporting factor is the Community Empowerment variable with a value of 0.010 units, the reinforcing factor is the Policy Implementation variable with a value of -0.003 units.

According to Simamora in Agustino (2006), performance (performance) refers to the level of achievement of tasks that make up an employee's job). Performance reflects how well the employee meets the requirements of a job. The definition of performance is the recording of the results achieved in carrying out specific functions of a job or work activity during a certain period which is shown through the process or method of work and the results achieved. From the theory put forward, it is closely related to the effectiveness of the Effect of Policy Implementation, HR Competence, and Community Empowerment in government administration to improve the Performance of the Office for Women's Empowerment, Child Protection and Community Empowerment in Medan City.

\section{Implications and Findings of Research Results}

The results of the study have proven that the effect of policy implementation, apparatus competence, and community participation together has an effect on performance in the Office of Women's Empowerment, Child Protection and Community Empowerment in Medan City. The implication of this research is that there is a positive attitude of respondents or the community who give an attitude statement the three variables have an important role in realizing performance, by paying attention to policy implementation, competence and community participation. Indicators of Policy Implementation, Apparatus Competence and Community Participation which have an important or valid enough role in realizing performance in the Office of Women's Empowerment, Child Protection and Community Empowerment in Medan City are getting better. The government in every policy implementation must refer to the 1945 Constitution and other related regulations. The implementation of programs and activities for women's empowerment, child protection and community participation during 2018 resulted in main outputs consisting of 14 (fourteen) work programs including:

1. Office Administration Services Program

2. Apparatus Facilities and Infrastructure Improvement Program

3. Apparatus Discipline Improvement Program

4. Apparatus Capacity Building Program

5. Rural Community Empowerment Improvement Program

The Effect of Policy Implementation, Personnel Competency, and Community Participation on the Performance of the department of Women 
6. Rural Economic Institution Development Program

7. Gender and Child Mainstreaming Institutional Strengthening Program

8. Gender Mainstreaming (PUG) and Child Mainstreaming (PUHA) Institutional Strengthening Program

9. Program to Improve the Quality of Life and Protection of Women

10. Community Participation Improvement Program in Village Development

11. Program for Enhancing Participation and Gender Equality in Development

12. Program for Enhancing the Role of Women in Rural Areas

13. Medan City United Dharma Wanita Program

14. Program for Synchronization of Quality Improvement Policies for Children and Women

Meanwhile, related to budget realization, the implementation of programs and activities for women's empowerment, child protection and community participation during 2018 was supported by a budget allocation of Rp. 18,133,937,935, - consisting of Indirect Expenditures of Rp. 6,233,938,000, and Direct Expenditures of Rp. 11,899,999,935, - with the realization of Indirect Expenditures as of 31 December 2018 amounting to Rp. 6,008,090,809, - and the realization of Direct Spending as of 31 December 2018 of Rp. 7,480,304,428, - or $62.86 \%$.

In accordance with the findings above and efforts to improve performance at the Office for Women's Empowerment, Child Protection and Community Empowerment in Medan City, it is necessary to encourage:

1. Increasing Policy Implementation in promoting equitable, affordable, quality and just services.

2. Increasing Apparatus Competence through provision to increase the knowledge, skills and abilities of human resources both employees and the community.

3. Increase community participation by developing and utilizing natural resources that are evenly distributed and of good quality.

4. Improve employee performance which will have an impact on improving the performance of the organization / agency, in this case the Medan City DP3APM.

From this,a performance improvement model can be made at DP3APM Medan City,as shown in Figure 1.

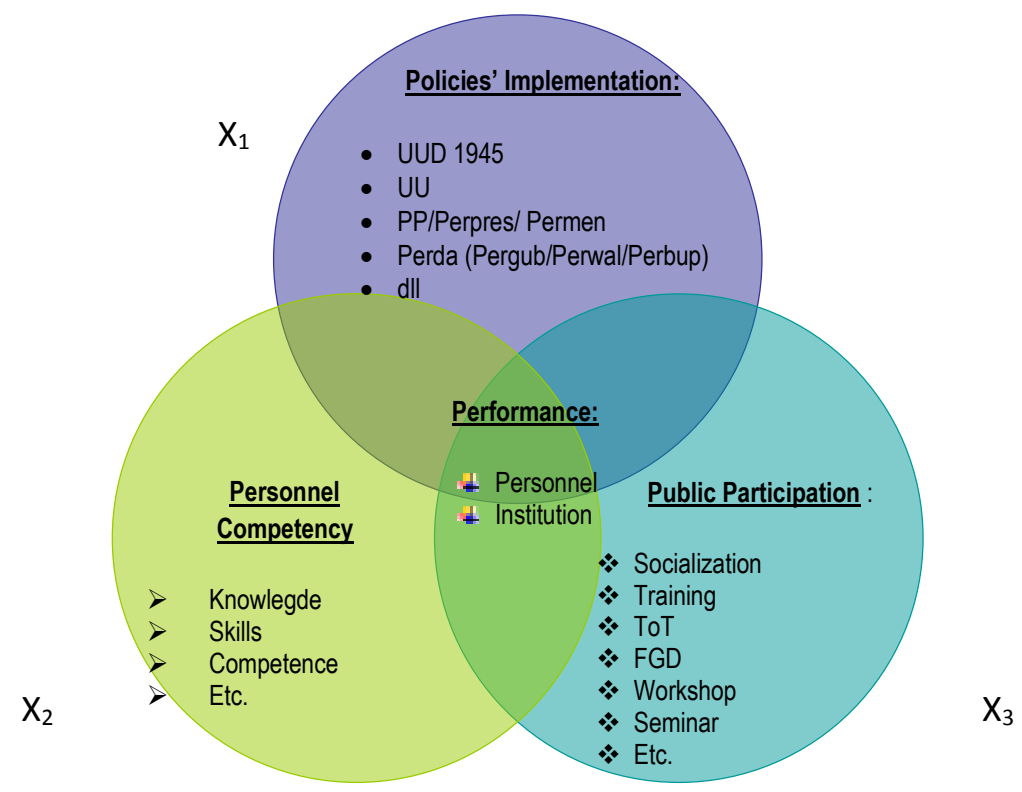

Figure 2. Model of DP3APM Performance Improvement in Medan City 
Based on Figure 2. The Model for Improving the Performance of DP3APM in Medan City, it can be explained that the implementation of policies from the 1945 Constitution, and statutory regulations to regional regulations, both Governor Regulations (Pergub), Regent Regulations (Perbup), and Mayor Regulations (Perwal) are expected to support the improvement. and development of Apparatus Competence in agencies / Regional Work Units (SKPD), as well as Community Participation which can be done through socialization, training, seminars, Trainning of Trainers (ToT), Focus Group Discussions (FGD) and Workshops, to improve performance at DP3APM Medan city.

\section{Conclusion}

The conclusions from the results of this study are:

1. There is a large influence of policy implementation on the organizational performance of the Office of Women's Empowerment, Child Protection and Community Empowerment (DP3APM) Medan City amounting to $83.6 \%$. This shows the importance of implementing policies on the organizational performance of the Office of Women's Empowerment, Child Protection and Community Empowerment (DP3APM) Medan City.The simple linear regression equation formed between the Policy Implementation variable $(\mathrm{X} 1)$ and performance $(\mathrm{Y})$ is $\hat{\mathrm{Y}}=2.305+0.962 \mathrm{X} 1$. The results of these statistics indicate that the implementation of policies makes a significant contribution to performance. That is, the better the Policy Implementation, the better the performance with the Beta Coefficient value of 0.962. As for those who play a role in the policy implementation variable, it can be seen from the highest $r$-count value of 0.583 , namely the behavioral norm indicator. While the lowest was 0.181 , namely the Cost indicator.

2. There is a large influence of Apparatus Competence on the organizational performance of the Office of Women's Empowerment, Child Protection and Community Empowerment (DP3APM) Medan City by 99.9\%. This shows the importance of Apparatus Competence in the organizational performance of the Office of Women's Empowerment, Child Protection and Community Empowerment (DP3APM) Medan City. The simple linear regression equation formed between the Apparatus Competence (X2) and performance $(\mathrm{Y})$ variables is $\hat{\mathrm{Y}}=-0,122+1,002 \mathrm{X} 2$. These statistical results indicate that Apparatus Competence makes a significant contribution to performance. This means that the better the Apparatus Competence, the better the performance with the Beta Coefficient value of 1.002. As for those who play a role in the Apparatus Competence variable with the highest r-count value of 0.610, namely the indicator of attention and knowledge development, while the lowest is the indicator of cooperation.

3. There is a large influence of community participation on the organizational performance of the Office of Women's Empowerment, Child Protection and Community Empowerment (DP3APM) Medan City by 92.3\%. This shows the importance of community participation in the organizational performance of the Office of Women's Empowerment, Child Protection and Community Empowerment (DP3APM) Medan City. The simple linear regression equation formed between the Community Participation (X3) and performance $(\mathrm{Y})$ variables is $\hat{\mathrm{Y}}=-1,490+1,016 \mathrm{X} 3$. The results of these statistics indicate that community participation makes a real contribution to performance. This means that the better public participation, the better the performance with a Beta Coefficient value of 1.016. As for those who play a role in the community participation variable with the highest $r$-count value of 0.577 , namely the ability to solve problems, while the lowest is 0.197 , namely the indicator of government involvement in the health sector.

4. There is a large effect of policy implementation, HR competence and community participation together on the organizational performance of the Medan City Women's Empowerment, Child Protection and Community Empowerment Service (DP3APM) of 99.9\%, meaning that all variables are needed to interpret performance. In this case, the main factor affecting the organizational performance of the Office of Women's Empowerment, Child Protection and Community Empowerment (DP3APM) Medan City. The recapitulation of the beta coefficient value is divided into main factors, supporting factors, and

The Effect of Policy Implementation, Personnel Competency, and Community Participation on the Performance of the department of Women Empowerment, Child Protection and Community Empowerment, Medan, Indonesia 
reinforcing factors. The main factor affecting performance is the Apparatus Competency variable with a value of 0.996 units, the supporting factor is the Community Participation variable with a value of 0.010 units, the reinforcing factor is the Policy Implementation variable with a value of -0.003 units. The highest r-value is 0.621 , which is the Needs indicator. While the lowest was 0.209 , namely the Expectation indicator.

The suggestions are as follows:

1. Further research is needed by adding variables such as: leadership and training. Policy implementation can be carried out well if there is exemplary from the leadership and official officials, in addition to counseling. In formulating a policy, the State apparatus must always pay attention to the aspirations that grow and develop in society and accommodate them with various considerations, so that a truly impartial policy is achieved. to the public interest. Especially in the current reform era, officials are expected to be able to formulate policies in accordance with the spirit of reform, namely taking the interests of the people, being fair and bringing prosperity to all levels of society.

2. It is hoped that the Office of Women's Empowerment, Child Protection and Community Empowerment (DP3APM) of Medan City will provide competency assessments to its employees, the purpose of the work competency assessment carried out by agencies is to obtain objective consideration in developing employees and to find out their abilities and skills. of employees, in this case employees as human resources.

3. Regional leaders are needed who are willing to understand and have determination in community development and empowerment by improving the economy, as well as knowing that one of the roles of facilitating economic activity is the Department of Women's Empowerment, Child Protection and Community Empowerment (DP3APM) Medan City greatly influences the increase of economic empowerment. Community empowerment can be pursued through seminars, training, Training of Trainers (ToT), Focus Group Discussions (FGD), and workshops especially for community groups.

4. The organization should be able to have more control over its employees during working hours, and also check whether the employee actually comes to work or not. So that no more employees violate the rules during working hours and give warnings or penalties for employees who do so. The organization must have a record of employee relationship data that can be used as a reference for assessing employee performance.

\section{References}

Agustino, Leo, 2006, Dasar-dasar Kebijakan Publik, Bandung : CV. Alfabeta.

Armstrong, M. and Baron, A. 1998. Performance Management - The New Realities. London: Institute of Personnel and Development.

Dinas P3APM Kota Medan, 2019.

Indrajaya, 2017 Indrajaya, Johan Arief. 2017. Pengaruh Kompetensi Aparatur Desa Dan Implementasi Undang-Undang- No. 6 Tahun 2014 Terhadap Pengelolan Keuangan Desa; Jurnal Universitas Lampung.

Jim Ife dan Frank Tesoreiro, 2008, Alternatif Pengembangan Masyarakat di Era Globalisasi Community Development, Yogyakarta: Pustaka Pelajar.

LAKIP Pemkot Medan, 2015. 
Peraturan Presiden Nomor 2 Tahun 2015 tentang Rencana Pembangunan Jangka Menengah Negara (RPJMN) 2015-2019.

Robbins, SP., 2005, Perilaku Organisasi, terjemahan : Tim Indeks, : Kelompok Gramedia Group, Jakarta.

Sugiyono 2010 Sugiyono. 2010. Metode Penelitian Bisnis (Pendekatan Kualitatif, Kuantitatif dan R\&D). Bandung: Alfabeta.

Tachjan, 2006, Implementasi Kebijakan Publik, AIPI, Bandung.

Undang-Undang Dasar 1945.

Wahab, Solihin Abdul, 2002, Pengantar Analisis Kebijaksanaan Negara, Jakarta : Rineka Cipta.

\section{Copyrights}

Copyright for this article is retained by the author(s), with first publication rights granted to the journal.

This is an open-access article distributed under the terms and conditions of the Creative Commons Attribution license (http://creativecommons.org/licenses/by/4.0/). 